\title{
Informatic Video Increased the Number of Acceptors in Postplacental Insertion of Intrauterine Device (IUD)
}

\author{
Video Informasi Meningkatkan Jumlah Akseptor Alat Kontrasepsi Dalam Rahim (AKDR) \\ Pascaplasenta
}

\author{
Gladys Susanty, Eddy Tiro, Fatmawaty Madya, Isharyah Sunarno \\ Mardiah Tahir, Telly Tessy
}

Department of Obstetrics and Gynecology

Faculty of Medicine Universitas Hasanuddin

Dr. Wahidin Sudirohusodo General Hospital

Makassar

\begin{abstract}
Objective : To find out the role of informatic video in obtaining consent for post placental insertion of Intrauterine Device (IUD).

Methods : This was a prospective randomized controlled trial. The informatic video was given to the study group compared by the level of acceptance of the respondents in the control group that was given conventional methods. This research was carried out in Pertiwi, Fatimah, and Khadijah I Mother and Child Hospital Makassar. The data were analyzed by chi-square test with significant level $p<0.05$.
\end{abstract}

Results : There was a significant correlation between informatic video groups to the consent $(p=0.026)$ and the insertion $(p=0.034)$ of post placental IUCD. The informatic video had the effects to increased the number of acceptors post placental IUCD with the value of significance as 0.018 , therefore if the informatic video was increased, then the consent of insertion IUCD was also increased.

Conclusions : Informatic video had the effects of increased the number of acceptors postplacental IUCD.

Keywords : informatic video, postplacental insertion of Intra-Uterine Contraceptive Device (IUCD).

\begin{abstract}
Abstrak
Tujuan : Mengetahui hubungan antara video informasi dalam pengambilan persetujuan tindakan medis pada pemasangan AKDR pasca plasenta.

Metode : Penelitian ini merupakan penelitian kohort dengan uji acak terkontrol prospektif. Jenis penelitian ini adalah penelitian uji kohort dimana peneliti memberikan tayangan video informasi pada kelompok penelitian serta membandingkan tingkat penerimaan pasien terhadap AKDR dengan kelompok kontrol. Penelitian ini dilaksanakan di Rumah Sakit Khusus Daerah Ibu dan Anak Pertiwi, Rumah Sakit Khusus Daerah Ibu dan Anak Fatimah, Rumah Sakit Ibu dan Anak Khadijah I Makassar. Data dianalisis dengan uji chi-square dengan kemaknaan $p<0,05$.

Hasil : Terdapat hubungan yang bermakna antara pemberian video informasi terhadap persetujuan $(p=0,026)$ dan pemasangan $(p=0,034)$ AKDR pascaplasenta. Video informasi memiliki pengaruh dalam meningkatkan jumlah akseptor AKDR pascaplasenta dengan nilai signifikansi sebesar 0,018, sehingga jika bantuan video informasi meningkat maka keputusan dalam pemasangan AKDR juga meningkat.
\end{abstract}

Kesimpulan : Video informasi memiliki pengaruh dalam meningkatkan jumlah akseptor AKDR pascaplasenta.

Kata kunci : AKDR pascaplasenta, video informasi. 


\section{INTRODUCTION}

Family Planning (KB) is an effort to regulate pregnancy, birth, distance and ideal age for childbirth, through promotion, protection and assistance in accordance with reproductive rights to create quality families. ${ }^{1}$ In an effort to improve maternal health, the main goal of family planning programs is for unmet need groups, and postpartum mothers are a very important target. Therefore, postpartum contraception is a strategic effort in Reducing Maternal Mortality Rate (MMR), as well as Infant Mortality Rate (IMR) where the number of births in Indonesia is very large, estimated at around 4,500,000 annually and 760,000 (17\%) in including an unwanted or unplanned birth (KTD). ${ }^{2,3}$

Intrauterine Device (IUD) is contraception that is often recommended for postpartum mothers as a type of contraception because it is more effective than other types of contraception in terms of the effect on lactation or effectiveness in preventing pregnancy. ${ }^{4,5}$ In mothers who have limited access to medical services, during labour is an opportunity to get contraceptive services, especially IUD insertion. Compared with sterilization, the use of IUD is more straightforward, a low cost relatively and high reversibility rate. ${ }^{5}$

Based on data of the Indonesian Demographic and Health Survey (SDKI), IUD contraception tended to decrease from $8.1 \%$ to $4.9 \% .1$ In South Sulawesi, the insertion of IUD contraception in postpartum is around 3,158 women or $6,77 \%$ of all new patients who received postpartum contraception. This number has not met the national target. ${ }^{4}$

Many factors cause low interest in using IUD. Among them are various kinds of myths in society regarding IUD insertion such as can cause infertility, abortion, discomfort in intercourse, cancer, IUD can move, IUD can come out, and IUD can injure the husband's penis. ${ }^{6}$ The lack of society understanding of the IUD has caused reluctance to use the IUD. ${ }^{6-8} \mathrm{~A}$ new method is needed to introducing the IUD to society through an easierto-understand method by using information videos.

Informed consent to medical care service requires an explanation of the right information including a clear description about the installation technique, advantages and side effects of IUD. ${ }^{9}$ Video has been claimed as one of the more successful media in capturing patient attention compared to other methods in delivering information. ${ }^{10}$ We aim the role of informatic video in obtaining consent for post placental insertion of IUD in several maternal and child hospitals in Makassar.

\section{METHODS}

This was a prospective randomized controlled trial. Subjects were pregnant women who performed antenatal care (ANC) in the third trimester at Pertiwi, Fatimah, and Khadijah I Mother and Child Hospital Makassar from May to September 2018. The total samples were 200 patients, divided into two group: 100 study group with informatics video and counselling, and 100 control group with conventional counselling only. Of the total samples, 85 patients agreed on the study group and 71 patients in the control group. The research team gave the information to the subject, then asked to fill out a questionnaire regarding the factors that influence the decision to use a postplacental IUD. Subjects who said they were willing to use a post placental IUD were asked to sign a written informed consent.

The inclusion criteria were pregnant women in the third trimester who performed antenatal care (ANC) and will give birth in Mother and Child Hospital, ready to use IUD, and fill out inform consent. The exclusion criteria were pregnant women with postpartum complication (postpartum bleeding, infection, rest placenta) and had the risk of postpartum infection.

Data were analyzed by continuity correction and chi-square test to see the relationship between the independent variables on the dependent variable and linear regression test to see variables that influence the decision to use IUD contraception. Data were processed with the help of Statistical Product and Service Solutions (SPSS) for Windows version 23.0.

Before this research was conducted, the researchers requested ethical clearance from the commission of ethical biomedical research at the Faculty of Medicine, Universitas Hasanuddin Makassar, with number: 297 / 114.8.4.5.31 / PP36KOMETIK / 2018. 


\section{RESULTS}

We included 200 subjects, 44 of them were excluded due to their refusal to participate. Then 156 subjects were randomized. We analysed 85 subjects in the study group and 71 subjects in the control group. Characteristics of the subjects are presented in table 1.

Table 1. Characteristics of the Subjects

\begin{tabular}{|c|c|c|c|}
\hline Characteristics & $\begin{array}{l}\text { Study group } \\
(\mathrm{n}=85, \%)\end{array}$ & $\begin{array}{c}\text { Control group } \\
(n=71, \%)\end{array}$ & P-value \\
\hline \multicolumn{4}{|l|}{ Age (years) } \\
\hline$<20$ & $6(7.1)$ & $5(7)$ & 0.999 \\
\hline $20-35$ & $62(72.9)$ & $52(73.2)$ & \\
\hline$>35$ & $17(20)$ & 14 (19.7) & \\
\hline \multicolumn{4}{|l|}{ Parity } \\
\hline Primipara & $28(32.9)$ & $25(35.2)$ & 0.924 \\
\hline Multipara & $47(55.3)$ & $37(52.1)$ & \\
\hline Grande Multipara & $10(11.8)$ & $9(12.7)$ & \\
\hline \multicolumn{4}{|l|}{ Education } \\
\hline High & $50(58.8)$ & $53(74.6)$ & 0.056 \\
\hline Low & $35(41.2)$ & $18(25.4)$ & \\
\hline \multicolumn{4}{|l|}{$\begin{array}{l}\text { Health Worker } \\
\text { support }\end{array}$} \\
\hline Supportive & 79 (92.9) & $63(88.7)$ & 0.526 \\
\hline Unsupportive & $6(7.1)$ & $8(11.3)$ & \\
\hline \multicolumn{4}{|l|}{ Husband } \\
\hline \multicolumn{4}{|l|}{ Support } \\
\hline Supportive & $68(80)$ & $56(78.9)$ & 1.000 \\
\hline Unsupportive & $17(20)$ & 15 (21.1) & \\
\hline \multirow{2}{*}{\multicolumn{4}{|c|}{$\begin{array}{l}\text { History of } \\
\text { Contraception }\end{array}$}} \\
\hline & & & \\
\hline No & $32(37.6)$ & $39(54.9)$ & 0.118 \\
\hline Pill & $11(20.8)$ & $2(6.2)$ & \\
\hline Injection 4 weeks & $2(3.8)$ & $5(15.6)$ & \\
\hline Injection 12 weeks & $18(34)$ & $13(40,6)$ & \\
\hline Implant & $15(25)$ & $10(31.2)$ & \\
\hline AKDR & $7(13.2)$ & $2(6.2)$ & \\
\hline
\end{tabular}

Based on the table above, each group showed the majority of patients in the age group 20-35 years, multipara, higher education, health worker support and husband support. The results of statistical tests show that age, parity, education, health worker support, husband support, and history of contraception are found to be $p$ value> 0.05 at a significance level of $95 \%$, meaning that the above variables do not have a correlation with the patient's decision to obtain an information video.

Table 2. Correlation of the Decisions of Patients who Obtained Informatics Video

\begin{tabular}{ccccc}
\hline Variable & Study & Control & Total & P-value \\
\hline \multicolumn{5}{c}{ Consent $(\mathbf{n}=\mathbf{2 0 0 ,} \%)$} \\
Yes & $85(85)$ & $71(71)$ & $156(78)$ & \\
No & $15(15)$ & $29(29)$ & $44(22)$ & 0.026 \\
Total & 100 & 10 & 200 & \\
\multicolumn{5}{c}{ Insertion $(\mathbf{n}=\mathbf{1 5 6})$} \\
Yes & $79(92.9)$ & $57(80.3)$ & $136(87.2)$ & \\
No & $6(7.1)$ & $14(19.7)$ & $20(12.8)$ & 0.034 \\
Total & 85 & 71 & 156 \\
\hline
\end{tabular}

Base on continuity correction test, the two variables show the value of $p$-value obtained is $<0.05$ at a significance level of $95 \%$, so that patients who agree, have a correlation with the patient's decision to obtain informatic video, as well as the IUD insertion. Patients who have agreed to the IUD insertion have a correlation with the patient's decision to obtain an informatic video (Table 2).

Table 3. Significant Test of the Effect of Informatic Video on Postplacental Insertion of IUD

\begin{tabular}{|c|c|c|c|c|c|}
\hline \multirow[t]{2}{*}{ Model } & \multicolumn{2}{|c|}{$\begin{array}{l}\text { Unstandardized } \\
\text { Coefficients }\end{array}$} & \multirow{2}{*}{$\begin{array}{c}\begin{array}{c}\text { Standardized } \\
\text { Coefficients }\end{array} \\
\beta\end{array}$} & \multirow[t]{2}{*}{$\mathbf{t}$} & \multirow[t]{2}{*}{ Sig } \\
\hline & $\beta$ & Std. Error & & & \\
\hline (Constant) & 1.138 & 0.139 & & 8.206 & 0.000 \\
\hline Insertion & 0.281 & 0.118 & 0.189 & 2.383 & 0.018 \\
\hline
\end{tabular}

Table 3. shows the significance of informatic video on post placental insertion of IUD. The results show a significance of 0.018 . A significance level of $0.018<0.05$; this means that informatic video assistance is significant or influences the patient's decision to IUD insertion. The coefficient value of 0.018 is positive so that if the informatic video assistance increases, the patient's decision to IUD insertion will also increase.

\section{DISCUSSION}

In this study, most maternal age of patients was low-risk age group, around 20-35 years old. This is in accordance with the demographic conditions of the Indonesian population where the structure of the population of Indonesia includes the structure of the youngest population with the most reproductive age, as well as in Makassar, South Sulawesi. ${ }^{11}$

Most of the patients are multiparous; this is in accordance with the purpose of the IUD, namely to make the distance of pregnancy so that for women of childbearing and multiparous age what is needed is a long-term contraceptive method. ${ }^{12}$ IUD acceptors are women who do not want to get pregnant and their motivation 
to install contraception is still high, especially in multiparous women. ${ }^{13}$

The results of our study found no significant association with education, parity and age on the level of decision to use IUD. The high level of education may not necessarily affect the level of decision in accepting IUD insertion. This can occur due to the influence of the quality of the counsellor in providing education to IUD acceptors. In accordance with a systematic review study, it was reported that there were differences in the success rates of IUD reception between public hospitals and clinics or home visits. ${ }^{14}$

Based on the results of our study, it was found that the husband's support was one of the factors that correlated the level of decision making for IUD insertion. The same results with the study that there is a relationship between the husband's support for the level of IUD insertion decisions. The purpose of using contraception is the goal of reproductive health which is a common goal of the family, especially the husband. Determining the desired number of children, when to postpone, place or end a pregnancy is a big decision and is the result of discussion between the wife, husband and family. Mothers supported by their husbands will find it easier to family planning programs and to make repeat visits or consult if there are things that are needed. ${ }^{15,16}$

The results of our study also found that the support of health workers had a correlation with the level of decision for IUD insertion. In accordance with the research conducted, where the relationship between the attitudes of officers and the use of IUD contraceptive services was reported. There was a significant correlation between staff support and the level of IUD insertion. Health workers are one of the reinforcing factors in IUD insertion. ${ }^{15,16}$ Our study result can be explained that the support and attitudes of officers greatly influence the knowledge of IUD acceptors.

Previous KB usage history shows that experience has a strong influence on the selection of family planning methods, this is consistent with research that contraceptive methods have a strong relationship with the methods used previously, even $91 \%$ of women in Indonesia still choose the same contraceptive method after one year later. ${ }^{17}$

\section{Comparison of Postplacenta IUD Consent and Insertion}

In this study, 44 patients refused to use the postplacental IUD, 15 patients in the video group and 29 patients in the conventional group. Reasons for refusing also varied, from the video group found six patients wanted to use another method of contraception, four patients because the IUD could interfere with intercourse, two patients because the husband did not agree, and three patients were still hesitant to use contraception. While from 29 patients in the conventional group, 15 patients also chose to use another method of contraception, eight patients because the husband did not support, four patients were still hesitant to use contraception, and two patients because they interfered with intercourse. The existence of myths is one of the bases of rejection of post placental IUD insertion, this is determined by the attitude of the patient who has an influence in determining the IUD consent and insertion. ${ }^{16}$

In this study also prioritizes the autonomy rights of the respondents as patients, this is consistent with research that the most important principle of counselling is the autonomy of clients and their own decision making which aims to protect clients and medical personnel.

The results of this study found that the informatic video had a significant association with the level of consent for post placental IUD insertion..$^{18}$ Our results show that of 200 samples which were divided into video groups and conventional groups, the rejection of post placental IUD insertion was higher in the conventional group (29\%) refused to use the IUD and showed significant results in terms of consent $(p=0.026)$. Knowledge has a correlation with the installation of IUD, so it is logical that all sources that are the place to obtain this knowledge will also affect the level of IUD insertion. ${ }^{19} \mathrm{~A}$ person's knowledge is usually obtained from various sources, such as mass media, electronic media, manuals, health workers, etc. Based on research, correct socialization can avoid the occurrence of misunderstandings and mistakes so that a method of providing adequate information media is needed in providing understanding to the public. In addition, there was also a multimedia theory called the multimedia principle proposed which 
states that "humans learn more than words and images compared to just words". ${ }^{20}$

In this study it was found that the use of informatic video gave a significant result of 0.018 greater than the conventional method, this is consistent that using video is very clearly acceptable to patients, because video provides an ideal solution regarding doubts that experienced by patients with consistency, structured, clear, and easily understood to facilitate and increase the active role of patients in making decisions. ${ }^{10}$

The strength of this study that this is a cohort study that patients followed starting from counselling, consent to post placental IUD insertion. All the factors that can influence the results of this study indicate a homogeneity so that confounding factors can be controlled.

The disadvantage of this study is that the informatic video displayed is only a procedure for post placental IUD insertion while overall counselling still uses the conventional method. This study was also limited in providing counselling only in the third trimester. In addition, counselling cannot be monitored one by one in the decisionmaking process. In this study, it does not aim to determine the best counselling procedure but to be the basis for developing an instrument to help effective counselling, so further research is still needed.

\section{CONCLUSIONS}

Informaticvideowith conventional counselling had the effects to increased the number of acceptors post placental IUCD. The more modalities used to provide information, the better the perceptions that can improve the decision making of post placental IUD insertion.

\section{REFERENCES}

1. Kementerian Kesehatan Republik Indonesia. Profil Kesehatan Republik Indonesia 2015. Jakarta. 2016.

2. Soendoro T. RISKESDAS 2007. Jakarta: Badan Penelitian dan Pengembangan Kesehatan Departemen Kesehatan RI. 2008.

3. BkkbN, L. Faktor - Faktor yang Mempengaruhi Penggunaan MKJP di Enam Wilayah Indonesia, Jakarta, BkkbN. 2015.
4. Kemenkes. KB pada Periode Menyusui: Hasil kajian HTA tahun 2009, Jakarta, Dirjen Bina Pelayanan Medik Kementrian Kesehatan Republik Indonesia. 2010.

5. Kementerian Kesehatan Republik Indonesia. Buletin Jendela Data dan Informasi Kesehatan. Jakarta. 2013.

6. Manju Shukla SQ, Chandrawati. Post-placental intrauterine device insertion - A five year experience at a tertiary care centre in north India. Ind J Med Research. 2012;136:432-5

7. McKaig C, Blanchard H. The IUD: A Contraceptive Option for Postpartum and Postabortion Women. Access Family Planning Initiative. 2010.

8. Association of Reproductive Health Professionals. Birth Control: Dispelling Common Myths about Intrauterine Contracept. 2013.

9. Khan ME, Kar SS, Desai VK, Patel P. Increasing the Accessibility, Acceptability and Use of the IUD in Gujarat, India. USAID. 2008.

10. Mason AV, Walker D, Barrett $S$, James D. The use of video information in obtaining consent for female sterilisation: a randomised study. BJOG, 2003;110:106271

11. Badan Pusat Statistik Provinsi Sulawesi Selatan. Provinsi Sulawesi Selatan dalam Angka 2018. 2018.

12. Utami SH, Desmiwati, Endrinaldi. Faktor-Faktor yang Berhubungan Dengan Unmet Need KB Pasca salin IUD post-Placenta di Kamar Rawat Pascabersalin RSUP DR. M.Djamil periode Januri-Maret 2013. Jur Kes Andalas. 2013;2(3):1-6.

13. Gupta S, Trivedi SS, Biswas R. A comparative Study of Clinical Outcomes of Post Placental Insertion Versus Internal Insertion of Copper T380A Intrauterine Device. Int J Reprod, Contracept, Obstet Gynecol. 2015;4(3):765-9.

14. Karra $M$, Canning $D$, Foster $S$, Shah $I H$, Senanayake $H$, Ratnasiri $U$, et al. Location and Content of Counselling and Acceptance of Postpartum IUD in Sri Lanka. Reprod Health. 2017;14(1):42.

15. Widiyawati S. Faktor-Faktor yang Berhubungan Dengan Pemakaian AKDR di Wilayah Kerja Puskesmas Batuah Kutai Kartanegara. Universitas Hasanuddin. 2012.

16. Pandiangan R. Faktor-Faktor yang Mempengaruhi Akseptor KB dalam Penggunaan Alat Kontrasepsi IUD di Wilayah Kerja Puskesmas Siempat Rube Kabupaten Pakpak Bharat Tahun 2017. Universitas Sumatra Utara. 2017.

17. Setiadi LI. Pengambilan Keputusan Penggunaan Alat Kontrasepsi Istri dalam Keluarga. Populasi. 2015;23(1):20-34.

18. Teshome M, Wolde Z, Gedefaw A, Mequanent T, Asefa A. Surgical Informed Consent in Obstetric and Gynecologic Surgeries: experience From A Comprehensive Teaching Hospital in Southern Ethiopia. Bio Med Ethics. 2018;19:38.

19. Notoatmojo S. Ilmu Kesehatan dan Ilmu Perilaku. Jakarta: Rineka Cipta. 2007.

20. Lin YK, Chen CW, Lee WC, Cheng YC, Lin TY, Lin CJ, et al. Educational Video-Assisted Versus Conventional Informed Consent for Trauma-Related Debridement Surgery: A Parallel Group Randomized Controlled Trial. Bio Med Central. 2018;19:23. 